\title{
Analisis Penilaian Kewajaran Harga Saham Dengan Menggunakan Pendekatan Fundamental Pada PT. Panin Sekuritas Tbk
}

\author{
Debi Carolina \\ Manajemen, STIE Mulia Darma Pratama Palembang \\ email :debby_chiby@yahoo.com
}

\begin{abstract}
ABSTRAK
Rumusan masalah dalam penelitian ini adalah bagaimana penilaian kewajaran harga saham dengan menggunakan pendekatan fundamental pada PT. Panin Sekuritas Tbk periode 2011-2016. Tujuan penelitian ini adalah untuk mengetahui penilaian kewajaran harga saham dengan menggunakan pendekatan fundamental pada PT. Panin Sekuritas Tbk periode 2011-2016. Sumber data yang digunakan adalah data sekunder. Pengumpulan data yang digunakan dalam penelitian ini adalah studi pustaka dan metode dokumentasi. Metode analisa data yang digunakan dalam penelitian ini adalah analisis kualitatif. Hasil analisis yang dilakukan dapat disimpulkan sebagai berikut: Pertama Apabila penilaian harga wajar saham menggunakan pendekatan fundamental dengan pendekatan PER atau estimasi PER pada PT. Panin Sekuritas, Tbk pada tahun 2011 sampai tahun 2014 berada pada kondisi overvalued (mahal) kemudian pada tahun 2015 dan tahun 2016 saham PT. Panin Sekuritas Tbk berada pada kondisi undervalued. Kedua Apabila harga saham dinilai dengan rasio nilai pasar, saham PT. Panin Sekuritas, Tbk jika dinilai menggunakan pendekatan price earning ratio (PER) pada tahun 2011 sampai tahun 2013 berada pada kondisi undervalued(murah) sedangkan untuk tahun 2014 sampai tahun 2016 sebaiknya saham tersebut dijual karena berada pada kondisi overvalued (mahal). Sedangkan saham PT. Panin Sekuritas, Tbk apabila dinilai menggunakan price to book value ratio (PBV) pada tahun 2011 sampai tahun 2016 saham berada pada kondisi undervalued atau murah.
\end{abstract}

Kata Kunci : Harga Saham, Kewajaran Harga Saham, PER dan PBV.

\section{A. Pendahuluan}

Pasar modal sebagai salah satu sumber pembiayaan bagi dunia usaha dan wahana investasi bagi masyarakat sangat berperan dalam pembangunan nasional. Kegiatan investasi di pasar modal ini dilakukan dengan cara membeli saham, obligasi maupun instrumen pasar modal lainnya. Keputusan investor untuk melakukan investasi dapat diartikan sebagai pengorbanan konsumsi pasar masa kini dengan harapan akan mendapatkan konsumsi yang lebih besar pada masa yang akan datang.

Peran yang dilakukan oleh pasar modal adalah menyediakan fasilitas untuk memindahkan dana, khususnya yang diperuntukan untuk pembiayaan jangka panjang, dari yang memiliki dana atau dikenal dengan istilah lender ke perusahaan yang membutuhkan dana atau borrower. Biasanya dalam menjalankan aktifitasnya pasar modal menggunakan jasa pialang dan underwriter. (Fahmi, 2014 : 306)

Dalam perkembangannya pasar modal Indonesia terus mengalami peningkatan sepanjang tahun. Secara umum peningkatan yang terjadi dapat dilihat dari perkembangan aktivitas pasar modal yang mencapai rata-rata volume perdagangan saham dan industri reksadana yang mengalami peningkatan yang signifikan dalam sepuluh tahun terakhir, baik dari jumlah reksa dana yang efektif, dana kelolaan, maupun jumlah pemegang unit penyertaan. Peningkatan jumlah reksadana ini juga diikuti peningkatan pada jumlah pemegang unit penyertaan.

Di pasar modal, investasi dalam saham merupakan salah satu pilihan 
favorit bagi investor. Seperti halnya investasi yang lain, investasi dalam saham juga tidak lepas dari resiko kerugian karena sifat komoditasnya yang peka terhadap perubahanperubahan yang terjadi baik perubahan eksternal maupun faktor internal perusahaan sehingga diperlukan analisis yang cermat dari investor sebelum memutuskan saham mana yang akan dipilih. Salah satu cara yang dapat dilakukan adalah dengan menganalisis harga saham perusahaan tersebut.

Saham adalah tanda bukti penyertaan kepemilikan modal atau dana pada suatu perusahaan atau kertas yang tercantum dengan jelas nilai nominal, nama perusahaan dan diikuti dengan hak dan kewajiban yang dijelaskan kepada setiap pemegangnya yang siap untuk dijual. (Fahmi, 2014 : 323)

Harga saham perusahaan dapat dikatakan sebagai indikator untuk menilai tingkat keberhasilan perusahaan. Semakin tinggi harga saham suatu perusahaan maka menunjukkan semakin tinggi tingkat keberhasilan perusahaan. Dan sebaliknya semakin rendah harga saham maka kemungkinan keberhasilan perusahaan juga semakin rendah. Dengan kata lain, harga saham dapat mencerminkan tingkat kepercayaan investor terhadap prospek perusahaan.

Untuk menilai harga saham suatu perusahaan tersebut ada berbagai teknik analisis yang dapat digunakan antara lain adalah analisis teknikal dan analisis fundamental. Analisis teknikal adalah analisis yang dilakukan dengan menggunakan data-data atau catatancatatan mengenai pasar yang telah dipublikasikan. Analisis ini sering dilakukan sebagai analisis pasar dan biasanya digunakan oleh investor jangka pendek. Sedangkan analisis fundamental didasarkan pada anggapan bahwa setiap saham mempunyai nilai intrinsik. Nilai intrinsik adalah suatu fungsi dari variabel perusahaan yang dikombinasikan untuk menghasilkan return yang diharapkan atau dengan kata lain nilai intrinsik adalah nilai yang sebenarnya atau seharusnya dari suatu saham. (Tandelilin, 2010 : 301)

Dalam analisis fundamental seorang analisis akan menganalisis faktor-faktor ekonomi yang mempengaruhi perusahaan untuk dapat memprediksikan perkembangan perusahaan dimasa yang akan datang sehingga dapat diketahui apakah harga saham tersebut undervalued atau overvalued. Analisis fundamental banyak dipakai oleh para investor jangka panjang. Analisis ini dapat dilakukan dengan menggunakan tiga macam pendekatan yaitu deviden approach, earning approach dan net tangiable approach. (Anoraga, 2006 : 62-64)

Dalam penelitian ini penilaian kewajaran harga saham menggunakan analisis fundamental yaitu dengan pendekatan earning approach. Karena analisis fundamental banyak dilakukan oleh akademisi. Dalam analisis fundamental ada dua pendekatan untuk menghitung nilai intrinsik saham, yaitu dengan pendekatan nilai sekarang (Present Value Approach) dan pendekatan rasio laba terhadap earning (Price Earning Ratio/PER). (Tandelilin, $2010:$ 303)

Price earning ratio adalah rasio yang dihitung dengan membagi harga saham saat ini dengan Earning Per Share (EPS). EPS sendiri merupakan rasio yang menunjukkan berapa besar laba per saham. PER dihitung dalam dalam satuan kali. Tentunya saham yang memiliki PER lebih tinggi berarti saham tersebut relatif mahal. Sebaliknya saham yang memiliki PER 
lebih kecil berarti saham tersebut relatif murah. Bagi para investor semakin kecil PER suatu saham semakin bagus. Tidak ada nilai yang pasti berapa sebaiknya PER suatu saham, umumnya investor menganggap nilai PER di bawah 10 adalah murah. Namun bila PER nya negatif artinya perusahaan itu sedang merugi (Wira, 2011:78).

Menurut Sudana (2011:23)

bahwa semakin tinggi price earning ratio suatu perusahaan maka menunjukkan bahwa investor mempunyai harapan yang baik tentang perkembangan perusahaan di masa yang akan datang, sehingga untuk pendapatan per saham tertentu, investor bersedia membayar dengan harga yang mahal.

Price to book valueratio (PBV) adalah rasio perbandingan antara harga pasar saham dan nilai buku per saham. Book value dapat digunakan untuk mengetahui apakah harga suatu saham saat ini murah atau mahal. Semakin rendah rasio PBV berarti harga saham tersebut bisa dianggap murah. Untuk BEI, rata-rata harga saham blue chip diperdagangkan sebesar 4-5 kali nilai bukunya (Wira, 2011:82).

Perbedaan dari kedua metode penilaian ini bahwa PER lebih populer dipakai di kalangan analisis saham dan praktisi dan rasio ini merefleksikan penilaian investor atas pertumbuhan keuntungan, risiko, dan efisiensi serta kondisi keuangan perusahaan dalam satu paket rasio yang sederhana.

Selain untuk mengetahui kondisi saham, penilaian kewajaran harga saham yaitu adalah untuk menilai kinerja perusahaan dan potensi pertumbuhan perusahaan dimasa yang akan datang dan untuk membantu investor untuk menentukan keputusan yang tepat dalam membeli, menahan atau menjual saham. Apabila saham tersebut berada pada kondisi overvalued maka investor akan mengambil sikap dengan melepaskan atau menjual saham tersebut, dan sebaliknya apabila berada di kondisi undervalued maka sebaiknya saham tersebut dibeli (Fahmi, 2014:437).

PT Panin Sekuritas yang berada di Gedung Bursa Efek Indonesia II, Lt.17 Ruang 1705, Jl.Jend.Sudirman Kav 52-53 Jakarta 12190, merupakan salah satu perusahaan efek besar dan berpengalaman untuk memenuhi kebutuhan para investor entah apakah itu investor perorangan, investor dari kalangan perusahaan swasta, atau pun investor dari lembaga pemerintahan.

PT Panin Sekuritas Tbk memiliki 2 anak perusahaan yaitu PT Panin Investment Management dan PT Panin Asset Management. Sesuai dengan ketentuan yang dikeluarkan oleh BAPEPAM-LK, kegiatan manajer investasi atau pengelolaan reksadana dialihkan ke anak perusahaan yaitu PT Panin Asset Management pada tahun 2011, sehingga PT Panin Sekuritas Tbk hanya melakukan kegiatan sebagai perantara pedagang efek dan melakukan transaksi jual beli saham di Bursa Efek Indonesia baik sistem online trading maupun melalui jasa equity sales yang telah memiliki izin perorangan dari Otoritas Jasa Keuangan sebagai wakil perantara pedagang efek.

\section{B. Kajian Teori \\ 1. Pengertian Pasar Modal}

Pasar modal adalah pertemuan antara pihak yang memiliki kelebihan dana dengan pihak yang membutuhkan dana dengan cara memperjualbelikan sekuritas. Dengan kata lain, pasar modal diartikan sebagai pasar untuk memperjualbelikan sekuritas yang umumnya memiliki umur lebih dari satu 
tahun seperti saham dan obligasi (Tandelilin, 2010:26).

Sedangkan menurut Joel $G$. Siegel dan Jae. K Shim ${ }^{1)}$ pasar modal adalah pusat perdagangan utang jangka panjang dan saham perusahaan. Adapun menurut R.J Shook $^{2}$ pasar modal merupakan sebuah pasar tempat dana-dana modal, seperti ekuitas dan hutang, diperdagangkan (Fahmi, 2014:305).

\section{Pengertian Saham}

Saham adalah sertifikat yang menunjukkan bukti kepemilikan suatu perusahaan, dan pemegang saham memiliki hak klaim atas penghasilan dan aktiva perusahaan (Rusdin, 2007:68).

Menurut Rusdin (2007:68) Nilai saham terbagi atas 3 jenis, yaitu :

a. Nilai Nominal (Nilai Pari)

Merupakan nilai yang tercantum dalam sertifikat saham yang bersangkutan, di Indonesia saham yang diterbitkan harus memiliki nilai nominal dan untuk satu jenis saham yang sama pada suatu perusahaan harus memiliki satu jenis nilai nominal.

b. Nilai Dasar

Pada prinsip harga dasar saham ditentukan dari harga perdana saat saham tersebut diterbitkan, harga dasar ini akan berubah sejalan dengan dilakukannya berbagai tindakan emiten yang berhubungan dengan saham, antara lain : Right Issue, Stock Split, Waran, dll.

c. Nilai Pasar

Merupakan harga suatu saham pada pasar yang sedang berlangsung, jika bursa sudah tutup maka harga pasar saham tersebut adalah harga penutupannya.

\section{Harga wajar saham}

Harga wajar saham adalah nilai atau harga yang sebenarnya dari perusahaan. Nilai pasar yang lebih kecil dari nilai intrinsiknya menunjukkan bahwa saham tersebut dijual dengan harga yang murah (undevalued), karena investor membayar saham tersebut lebih kecil dari yang seharusnya dia bayar. Dan sebaliknya nilai pasar yang lebih besar dari nilai intrinsiknya menunjukkan bahwa saham tersebut dijual dengan harga yang mahal (overvalued) (Jogiyanto, 2016:180).

\section{Penilaian Harga Wajar Saham}

Penilaian kewajaran harga saham menggunakan PER adalah apabila nilai PER dibawah 10 kali adalah murah. Namun PER yang tinggi atau lebih dari 10 kali bisa menunjukkan kalau perusahaan itu merupakan perusahaan yang diincar investor, sehingga harga sahamnya terus naik dan PER nya juga tinggi. Jika penilaian harga wajar saham menggunakan PBV, semakin rendah rasio PBV berarti harga saham tersebut bisa dianggap murah karena kebanyakan saham $\mathrm{BEl}$ rata-rata harga saham diperdagangkan sebesar4-5 kali nilai bukunya.

\section{Metode Penelitian}

1) Objek Penelitian

Objek penelitian ini adalah PT Panin Sekuritas Tbk di Gedung Bursa Efek Indonesia II, Lt.17 Ruang 1705, Jl.Jend.Sudirman Kav.52-53 Jakarta 12190.

2) Sumber Data

Sumber data yang digunakan dalam penelitian ini adalah data sekunder yaitu data yang diperoleh secara tidak langsung melalui buku-buku, situs internet dan literatur-literatur yang berhubungan dengan penelitian 
(www.idx.co.id/www.pans.co.id/w ww.ksei.co.id/www.finance.yahoo .com) yang berupa laporan keuangan perusahaan serta laporan pembagian dividen tunai periode 2011-2016.

\section{Teknik Pengumpulan Data}

Metode Pengumpulan data yang digunakan dalam penelitian ini adalah:

1. Studi Pustaka

Metode ini dilakukan dengan cara pengumpulan data yang didasarkan kepustakaan seperti informasi-informasi yang berkaitan dengan hal-hal yang diteliti berasal dari literatur-literatur, bacaanbacaan yang sesuai dan relevan dengan penelitian.

2. Metode Dokumentasi

Dengan melakukan studi pustaka dan berbagai literatur dan hasil browsing melalui internet seperti IDX melalui (www.idx.co.id), (www.pans.co.i d),(www.ksei.co.id), (www.finan ce.yahoo.com) serta berbagai situs lain yang berkaitan yang turut menunjang penelitian ini guna mendapatkan data (baik primer maupun sekunder).

\section{E. Teknik Analisis Data}

Dalam menganalisis data penulis menggunakan metode kualitatif. metode kualitatif adalah metode penelitian yang berlandaskan pada filsafat postpositivisme, digunakan untuk meneliti pada kondisi objek yang alamiah, dimana peneliti sebagai instrumen kunci, teknik pengumpulan data yang dilakukan secara trianggulasi atau gabungan, analisis data bersifat induktif/kualitatif dan hasil penelitian kualitatif lebih menekankan makna daripada generalisasi. (Sugiyono, 2013:14).

Metode analisis data yang digunakan dalam penelitian ini adalah metode kualitatif, Adapun langkahlangkah analisis data yang digunakan dalam penelitian ini adalah sebagai berikut:

1. Melihat harga saham dari periode 2011-2016.

2. Menghitung nilai intinsik atau harga wajar saham.

Nilai Intrinsik = Estimasi EPS $x$ PER

3. Menghitung nilai Estimasi Earning per share (EPS)

$\mathrm{E}_{1}=\mathrm{E}_{0}(1+\mathrm{g})$

Earning per Share (EPS)

EPS $=\frac{E A T}{J s b}$

4. Menghitung nilai Price Earning

Ratio (PER)

$\mathrm{PER}=\frac{\mathrm{D} 1 / \mathrm{E} 1}{\mathrm{k}-\mathrm{g}}$

F. Hasil Penelitian

Penulis menganalisis permasalahan yang dirumuskan pada bagian awal, yaitu penilaian harga saham pada PT. Panin Sekuritas, Tbk dengan menggunakan analisis harga saham, pendekatan price earning ratio (PER) dan price to book value ratio (PBV). Perhitungan analisis harga saham ini dilakukan dengan cara melihat laba per lembar saham dan pertumbuhan yang disajikan di dalam laporan neraca dan laporan laba rugi, sehingga dapat memberikan gambaran tentang keadaan masing-masing dan penilaian posisinya pada saat ini. 


\section{Data Harga Saham pada PT. Panin Sekuritas, Tbk Periode 2011-2016}

Tabel 1

Data Harga Saham Pada PT Panin Sekuritas Tbk Periode 2011-2016 (Dalam Rupiah)

\begin{tabular}{|c|c|c|c|c|c|c|}
\hline Date & Open & High & Low & Close & $\begin{array}{c}\text { Adj } \\
\text { Close }^{*}\end{array}$ & Volume \\
\hline Dec 30, 2011 & 1.290 & 1.290 & 1.290 & 1.290 & 1.290 & 28.500 \\
\hline $\operatorname{Dec} 28,2012$ & 3.175 & 3.175 & 3.175 & 3.175 & 3.175 & - \\
\hline $\operatorname{Dec} 30,2013$ & 3.775 & 4.000 & 3.775 & 4.000 & 4.000 & 376.000 \\
\hline $\operatorname{Dec} 30,2014$ & 4.950 & 4.975 & 4.950 & 4.975 & 4.975 & 10.100 \\
\hline $\operatorname{Dec} 30,2015$ & 3.900 & 4.100 & 3.900 & 4.100 & 4.100 & 199.800 \\
\hline $\operatorname{Dec} 30,2016$ & 3.780 & 3.920 & 3.560 & 3.920 & 3.920 & 864.500 \\
\hline
\end{tabular}

Sumber : www.finance.yahoo.com (Data diolah 2017)

Dari tabel 1 di atas terlihat bahwa harga saham PT. Panin Sekuritas, Tbk periode 2011-2016 yang diukur dengan closing price (harga penutupan) selama enam tahun mengalami fluktuasi atau naik turun dimana harga tertinggi pada tahun 2015 yaitu sebesar $\mathrm{Rp} 4.975$ dan harga terendah yaitu pada tahun 2011 sebesar Rp 1.290. Naik turunnya harga saham ini dipengaruhi oleh kondisi mikro atau makro perusahaan.

\section{Data Dividen pada PT. Panin Sekuritas, Tbk Periode 2011-2016}

Tabel 2

Data dividen pada PT Panin Sekuritas Tbk Periode 2011-2016

\begin{tabular}{|c|c|c|c|c|c|c|c|}
\hline \multirow{2}{*}{ Variabel } & \multicolumn{7}{|c|}{ Tahun } \\
\cline { 2 - 8 } & $\mathbf{2 0 1 0}$ & $\mathbf{2 0 1 1}$ & $\mathbf{2 0 1 2}$ & $\mathbf{2 0 1 3}$ & $\mathbf{2 0 1 4}$ & $\mathbf{2 0 1 5}$ & $\mathbf{2 0 1 6}$ \\
\hline Dividen (Rp) & 50 & 80 & 100 & 115 & 115 & 420 & 80 \\
\hline $\begin{array}{c}\text { Dividen tunai } \\
\text { (Jutaan Rp) }\end{array}$ & 36.000 & 57.600 & 72.000 & 82.800 & 82.800 & 302.400 & 57.600 \\
\hline
\end{tabular}

Sumber : www.ksei.co.id (Data diolah 2017)

Berdasarkan tabel 2 pembagian dividen pada PT Panin Sekuritas, Tbk jika dilihat dari tahun 2010 yang hanya sebesar $\mathrm{Rp} 50$, mengalami peningkatan dari tahun 2011 sebesar Rp 80, tahun 2012 sebesar Rp 100, tahun 2013 dan 2014 sebesar Rp 115, tahun 2015 meningkat menjadi sebesar Rp 420 akan tetapi pada tahun 2016 jumlah dividen turun menjadi sebesar $\mathrm{Rp}$ 80. Dividen tunai pada PT. Panin Sekuritas, Tbk mengalami fluktuasi, tertinggi terjadi pada tahun 2015 sebesar Rp 302.400 dan terendah terjadi di tahun 2011 sebesar Rp 36.000. Perubahan tersebut dipengaruhi oleh pembagian dividen dan besarnya jumlah dividen ini bervariasi tergantung dari besarnya pendapatan perusahaan tersebut dan kebijakan alokasinya.

\section{Menghitung Nilai Intrinsik atau Harga Wajar Saham}

Nilai intrinsik $=$ Estimasi EPS $\times$ PER

Perhitungannya dapat dilihat dibawah ini:

$2011=\operatorname{Rp} 397,86 \times 3,00=\operatorname{Rp} 1.193$

$2012=\operatorname{Rp} 332,87 \times 9,33=R p 3.105$

$2013=\operatorname{Rp} 369,75 \times 10,00=R p 3.697$

$2014=\operatorname{Rp} 334,24 \times 14,00=\operatorname{Rp} 4.679$

$2015=\operatorname{Rp} 392,55 \times 11,50=\operatorname{Rp} 4.514$

$2016=\operatorname{Rp} 103,72 \times 39,17=\operatorname{Rp} 4.062$ 
Tabel 3

Nilai Intrinsik Saham PT. Panin Sekuritas Tbk periode 2011-2016

(Dalam rupiah)

\begin{tabular}{|c|c|}
\hline Tahun & Harga wajar \\
\hline 2011 & 1.193 \\
\hline 2012 & 3.105 \\
\hline 2013 & 3.697 \\
\hline 2014 & 4.679 \\
\hline 2015 & 4.514 \\
\hline 2016 & 4.062 \\
\hline \multicolumn{2}{|l|}{ Sumber : Data diolah (2017) }
\end{tabular}

Berdasarkan tabel 3 dapat diketahui bahwa yang hasil perhitungan nilai intrinsik atau harga wajar saham dengan menggunakan metode price earning ratio (PER) saham pada PT. Panin Sekuritas, Tbk harga wajar ditahun 2011 sebesar Rp 1.193, di tahun 2012 sebesar $R p$ 3.105, tahun 2013 sebesar Rp 3.697, tahun 2014 harga wajar sebesar Rp 4.679, tahun 2015 harga wajar sebesar Rp 4.514 dan ditahun 2016 harga wajar sebesar Rp 4.062.

\section{Menghitung Nilai Estimasi Earning per Share (EPS)}

$\mathrm{E} 1=\mathrm{E}_{0}(1+\mathrm{g})$

Perhitungan estimasi EPS adalah sebagai berikut :

$2011=\operatorname{Rp} 334,34 \times(1+0,1863 \%)=\operatorname{Rp} 397,86$

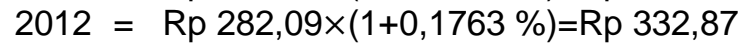

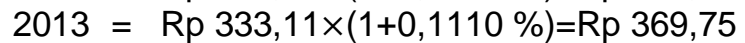

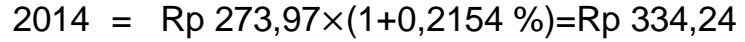

$2015=\operatorname{Rp} 509,80 \times(1+(-0,2268 \%)=\operatorname{Rp} 392,55$

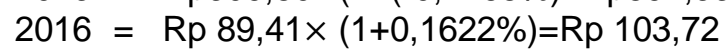

\section{Earning per Share (EPS)}

$\mathrm{EPS}=\frac{E A T}{J s b}$

Perhitungannya dapat dilihat dibawah ini :

$$
\begin{aligned}
& 2010=\frac{240.721 .978 .413}{720.000 .000}=\operatorname{Rp~334,34} \\
& 2011=\frac{203.106 .372 .557}{720.000 .000}=\operatorname{Rp} 282,09 \\
& 2012=\frac{239.840 .409 .758}{720.000 .000}=\operatorname{Rp} 333,11 \\
& 2013=\frac{197.258 .112 .131}{720.000 .000}=\operatorname{Rp} 273,97
\end{aligned}
$$

$$
\begin{aligned}
& 2014=\frac{367.057 .880 .223}{720.000 .000}=\operatorname{Rp~509,80} \\
& 2015=\frac{64.375 .761 .606}{720.000 .000}=\operatorname{Rp~89,41} \\
& 2016=\frac{259.502 .260 .167}{720.000 .000}=\operatorname{Rp~360,42}
\end{aligned}
$$

\section{Menghitung Nilai Price Earning Ratio (PER)}

$$
\mathrm{PER}=\frac{\mathrm{D} 1 / \mathrm{E} 1}{\mathrm{k}-\mathrm{g}}
$$

Perhitungan PER dapat dilihat dibawah ini :

$$
\begin{aligned}
2011 & =\frac{\text { Rp } 59,50 / \text { Rp } 397,86}{0,24-0,1863}=\frac{0,15}{0,05} \\
& =3,00 \text { dibulatkan } 3 \times \\
2012 & =\frac{\text { Rp } 94,40 / \text { Rp } 332,87}{0,21-0,1763}=\frac{0,28}{0,03} \\
& =9,33 \text { dibulatkan } 10 \times \\
2013 & =\frac{\text { Rp } 111,00 / \text { Rp } 369,75}{0,14-0,1110}=\frac{0,30}{0,03} \\
& =10,00 \text { dibulatkan } 10 \times \\
2014 & =\frac{\text { Rp } 140,30 / \text { Rp } 334,24}{0,25-0,2154} \\
& =\frac{0,42}{0,03}=14,00 \text { dibulatkan } 14 \times \\
2015 & =\frac{\text { Rp } 88,55 / \text { Rp } 392,55}{-0,21-(-0,2268)}=\frac{0,23}{0,02} \\
& =11,50 \text { dibulatkan } 12 \times \\
& =\frac{\text { Rp } 487,20 / \text { Rp } 103.72}{0,28-0,1622}=\frac{4,70}{0,12} \\
& =39,17 \text { dibulatkan } 40 \times
\end{aligned}
$$

a) Estimasi Discount Rate (k)

$$
\mathrm{k}=\frac{D 1}{P o}+\mathrm{g}
$$

Perhitungannya bisa dilihat dibawah ini :

$$
\begin{aligned}
& 2011=\frac{\operatorname{Rp} 59,50}{\operatorname{Rp} 1.290}+0,1863 \%=0,24=24,00 \% \\
& 2012=\frac{\operatorname{Rp} 94,40}{\operatorname{Rp} 3.175}+0,1763=0,21=21,00 \% \\
& 2013=\frac{\operatorname{Rp~} 111,00}{\operatorname{Rp} 4.000}+0,1110 \%=0,14=14,00 \% \\
& 2014=\frac{\operatorname{Rp~} 140,30}{\operatorname{Rp~} 4.975}+0,2154 \%=0,25=25,00 \%
\end{aligned}
$$




$$
\begin{aligned}
& 2015=\frac{\operatorname{Rp~} 88,55}{\operatorname{Rp} 4.100}+(-0,2268) \%=-0,21=-1,00 \% \\
& 2016=\frac{\operatorname{Rp~} 487,20}{\operatorname{Rp} 3.920}+0,1622 \%=0,28=28,00 \%
\end{aligned}
$$

\section{b) Estimasi Dividend per Share (DPS)}

$\mathrm{D} 1=\mathrm{D}_{0}(1+\mathrm{g})$

Perhitungannya dapat dilihat dibawah ini :

$$
\begin{aligned}
& 2011=\operatorname{Rp~} 50 \times(1+0,1863 \%)=\operatorname{Rp} 59,50 \\
& 2012=\operatorname{Rp} 80 \times(1+0,1763 \%)=\operatorname{Rp} 94,40 \\
& 2013=\operatorname{Rp} 100 \times(1+0,1110 \%)=\operatorname{Rp~111,00} \\
& 2014=\operatorname{Rp} 115 \times(1+0,2154 \%)=\operatorname{Rp~140,30}
\end{aligned}
$$

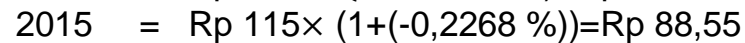

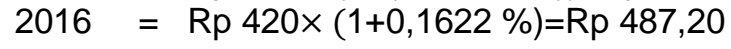

$>$ Dividend per Share (DPS)

DPS $=\frac{\text { Dividen }}{S S}$

Perhitungannya dapat dilihat dibawah ini :

$$
\begin{aligned}
& 2010=\frac{50}{720.000 .000}=\operatorname{Rp} 50 \\
& 2011=\frac{80}{720.000 .000}=\operatorname{Rp~} 80 \\
& 2012=\frac{100}{720.000 .000}=\operatorname{Rp~} 100 \\
& 2013=\frac{115}{720.000 .000}=\operatorname{Rp~} 115 \\
& 2014=\frac{115}{720.000 .000}=\operatorname{Rp~} 115 \\
& 2015=\frac{420}{720.000 .000}=\operatorname{Rp~} 420 \\
& 2016=\frac{80}{720.000 .000}=\operatorname{Rp~} 80
\end{aligned}
$$

\section{c) Tingkat Pertumbuhan (growth)}

$\mathrm{G}=\mathrm{ROE} \times \mathrm{b}$ dimana $\mathrm{b}=1-\mathrm{DPR}$

Perhitungannya dapat dilihat dibawah ini :

$$
\begin{aligned}
& 2011=25,88 \% \times(1-0,02836 \%)=18,63 \% \\
& 2012=25,18 \% \times(1-0,3002 \%)=17,63 \% \\
& 2013=19,14 \% \times(1-0,4197 \%)=11,10 \% \\
& 2014=27,98 \% \times(1-0,2255 \%)=21,54 \% \\
& 2015=6,13 \% \times(1-4,6974 \%)=-22,68 \% \\
& 2016=20,79 \% \times(1-0,2220 \%)=16,22 \%
\end{aligned}
$$

\section{Dividen Payout Ratio (DPR)}

DPR $=\frac{\text { Dividen }}{E A T}$

Perhitungannya dapat dilihat dibawah ini :

$$
\begin{aligned}
& 2011=\frac{80}{203 \cdot 106.372 \cdot 557}=0,283595=28,36 \% \\
& 2012=\frac{100}{239 \cdot 840.409 .758}=0,3002=30,02 \% \\
& 2013=\frac{115}{197 \cdot 258 \cdot 112 \cdot 131}=0,419755=41,97 \% \\
& 2014=\frac{115}{367.057 .880 .223}=0,225578=22,56 \% \\
& 2015=\frac{420}{64.375 \cdot 761 \cdot 606}=4,69742=469,74 \% \\
& 2016=\frac{80}{259 \cdot 502 \cdot 260.167}=0,221963=22,20 \%
\end{aligned}
$$

Return on Equity (ROE)

$\mathrm{ROE}=\frac{\text { EAT }}{\text { Total Equity }}$

Perhitungannya dapat dilihat dibawah ini :

$$
\begin{aligned}
& 2011=\frac{203 \cdot 106 \cdot 372 \cdot 557}{784 \cdot 756 \cdot 035 \cdot 836}=0,258815=25,88 \% \\
& 2012=\frac{239 \cdot 840 \cdot 409 \cdot 758}{952 \cdot 596 \cdot 445 \cdot 594}=0,251775=25,17 \% \\
& 2013=\frac{197 \cdot 258 \cdot 112 \cdot 131}{1 \cdot 030 \cdot 526 \cdot 466 \cdot 674}=0,191415=19,14 \% \\
& 2014=\frac{367 \cdot 057 \cdot 880 \cdot 223}{1 \cdot 311 \cdot 777 \cdot 829 \cdot 627}=0,279817=27,98 \% \\
& 2015=\frac{64 \cdot 375 \cdot 761 \cdot 606}{1 \cdot 050 \cdot 754 \cdot 220.213}=0,061266=6,12 \% \\
& 2016=\frac{259 \cdot 502 \cdot 260 \cdot 167}{1 \cdot 248 \cdot 127 \cdot 977 \cdot 927}=0,207913=20,79 \%
\end{aligned}
$$

Tabel 4

Hasil Perhitungan Nilai PER pada PT. Panin Sekuritas Periode Tbk 2011-2016

\begin{tabular}{|c|c|c|c|c|c|c|}
\hline \multirow{2}{*}{ Variabel } & \multicolumn{7}{|c|}{ Tahun } \\
\cline { 2 - 7 } & $\mathbf{2 0 1 1}$ & $\mathbf{2 0 1 2}$ & $\mathbf{2 0 1 3}$ & $\mathbf{2 0 1 4}$ & $\mathbf{2 0 1 5}$ & $\mathbf{2 0 1 6}$ \\
\hline PER $(\times)$ & 3 & 10 & 10 & 14 & 12 & 40 \\
\hline Discount rate (k) (\%) & 24,00 & 21,00 & 14,00 & 25,00 & $-21,00$ & 28,00 \\
\hline Est DPS (Rp) & 59,50 & 94,40 & 111,00 & 140,30 & 88,55 & 487,20 \\
\hline Est EPS (Rp) & 397,86 & 332,87 & 369,75 & 334,24 & 392,55 & 103,72 \\
\hline Growth (\%) & 18,36 & 17,63 & 11,10 & 21,54 & $-22,68$ & 16,22 \\
\hline DPR (\%) & 28,36 & 30,02 & 41,97 & 22,56 & 469,74 & 22,20 \\
\hline DPS (Rp) & 80 & 100 & 115 & 115 & 420 & 80 \\
\hline EPS (Rp) & 334,34 & 282,02 & 333,11 & 273,97 & 509,80 & 89,41 \\
\hline ROE (\%) & 25,88 & 25,18 & 19,14 & 27,98 & 6,13 & 20,79 \\
\hline
\end{tabular}

Sumber : Data diolah (2017) 
Berdasarkan tabel 4 dapat dilihat bahwa nilai Price Earning Ratio (PER) pada $\mathrm{PT}$.

Panin Sekuritas, Tbkmengalami fluktuasi dimana nilai PER terendah terjadi di tahun 2011 sebesar3 kali dan tertinggi pada tahun 2016 sebesar 40 kali. Peningkatan dan penurunan nilai PER disebabkan karena market price terus berubah-ubah akibat perubahan besarnya nilai ROE, EPS, DPR dan DPR.

Tingkat suku bunga atau Discount rate (k) pada PT. Panin Sekuritas, Tbk mengalami peningkatan di tahun 2016 sebesar 28,00 \% dan mengalami penurunan di tahun 2015 sebesar $21,00 \%$. Peningkatan dan penurunan yang terjadi dikarenakan nilai estimasi yang mengalami fluktuasi disetiap tahunnya.

Nilai estimasi DPS pada PT. Panin Sekuritas, Tbk setiap tahunnya mengalami fluktuasi, dimana nilai estimasi tertinggi terjadi pada tahun 2016 yaitu sebesar $R p$ 487,20 dan terendah pada tahun 2011 sebesar Rp 59,50 . Peningkatan dan penurunan yang terjadi dikarenakan adanya perubahan nilai DPS yang dibagikan dari tahun dasar dan juga dipengaruhi jumlah dividen dan jumlah saham yang beredar.

Nilai estimasi EPS pada PT. Panin Sekuritas, Tbk mengalami fluktuasi dimana nilai estimasi tertinggi terjadi pada tahun 2011 yaitu sebesar Rp 397,86 dan terendah pada tahun 2016 sebesar Rp 103,72. Peningkatan dan penurunan nilai estimasi EPS terjadi karena adanya perubahan nilai EPS dari tahun dasar yaitu tahun 2010 dan dipengaruhi oleh laba bersih dan jumlah saham beredar.

Tingkat pertumbuhan (growth) pada PT. Panin Sekuritas, Tbk mengalami fluktuasi dimana tingkat pertumbuhan yang tertinggi terjadi pada tahun 2014 sebesar $21,54 \%$ dan terendah pada tahun $2015-22,68 \%$. Peningkatan tingkat pertumbuhan disebabkan karena laba setelah pajak meningkat dan jumlah modal sendiri tetap, dan sebaliknya mengalami penurunan jika laba setelah pajak dan jumlah modal sendiri tetap atau berubah.

Nilai dividen payout ratio (DPR) pada PT. Panin Sekuritas, Tbk mengalami fluktuasi dimana tertinggi terjadi pada tahun 2015 yaitu sebesar $469,74 \%$ dan terendah terjadi pada tahun 2016 sebesar 22,20\%. Peningkatan yang terjadi yang disebabkan oleh meningkatnya jumlah dividen dan meningkatnya EAT dan penurunan nilai DPR karena meningkatnya jumlah dividen yang dibagikan dan tetap atau turunnya EAT.

Nilai DPS pada PT. Panin Sekuritas, Tbk tahun 2011 sampai 2015 nilai DPS mengalami kenaikan dari $R p 80$ sampai $R p 420$ akan tetapi pada tahun 2016 nilai DPS mengalami penurunan. Peningkatan nilai DPS terjadi karena disebabkan jumlah dividen yang dibagikan meningkat dan jumlah lembar saham yang beredar tetap, sedangkan untuk penurunan nilai DPS terjadi karena penurunan dividen yang dibagikan dan jumlah saham beredar tetap.

Nilai EPS pada PT. Panin Sekuritas, Tbk mengalami fluktuasi pada tanun 2011 sampai 2016 dimana pada tahun 2015 merupakan nilai EPS tertinggi yaitu sebesar $\mathrm{Rp} 509,80$ dan rendah terjadi pada tahun 2016 yang hanya sebesar Rp 89,41. Peningkatan ini disebabkan oleh kenaikan EAT dan jumlah lembar saham yang beredar tetap, sedangkan penurunan terjadi karena turunnya EAT dan jumlah saham beredar tetap atau terjadi peningkatan.

Nilai ROE pada PT. Panin Sekuritas, Tbk mengalami fluktuasi 
setiap tahunnya dimana nilai ROE tertinggi pada tahun 2014 sebesar $27,98 \%$ dan nilai ROE terendah yaitu pada tahun 2015 sebesar 6,13\%. Peningkatan yang terjadi disebabkan karena earning after tax (EAT) mengalami kenaikan sedangkan jumlah ekuitasnya tetap, sedangkan penurunan nilai ROE disebabkan oleh turunnya jumlah EAT dan jumlah ekuitasnya tetap atau lebih tinggi.

\section{Menghitung Nilai Price to Book Value Ratio (PBV)}

$\mathrm{P} / \mathrm{BV}=\frac{\text { Price of stock }}{\text { Book value per share }}$

dan diketahui :

$B V S=\frac{\text { Total Equity }}{\text { Number of outstanding shares }}$

Perhitungan book value per shares sebagai berikut :

$2011=\frac{784.756 .035 .836}{720.000 .000}=\operatorname{Rp} 1.090$

$2012=\frac{952.596 .445 .594}{720.000 .000}=\operatorname{Rp} 1.323$

$2013=\frac{1.030 .526 .466 .674}{720.000 .000}=\operatorname{Rp} 1.431$

$2014=\frac{1.311 .777 .829 .627}{720.000 .000}=\mathrm{Rp} 1.822$

$2015=\frac{1.050 .754 .220 .213}{720.000 .000}=\operatorname{Rp} 1.459$

$2016=\frac{1.248 .127 .977 .927}{720.000 .000}=\mathrm{Rp} 1.733$
Perhitungan PBV dapat dilihat dibawah ini :

PBV $2011=\frac{1.290}{1.090}=1,18 \times$

PBV $2012=\frac{3.175}{1.323}=2,40 \times$

PBV $2013=\frac{4.000}{1.431}=2,80 \times$

PBV $2014=\frac{4.975}{1.822}=2,73 \times$

PBV $2015=\frac{4.100}{1.459}=2,81 \times$

PBV $2016=\frac{3.920}{1.733}=2,26 \times$

Tabel 5

Data Nilai Price to Book Value Ratio pada PT. Panin Sekuritas Tbk Periode 2011-2016

\begin{tabular}{|c|c|}
\hline Tahun & PBV \\
\hline 2011 & $1,18 \times$ \\
\hline 2012 & $2,40 \times$ \\
\hline 2013 & $2,80 \times$ \\
\hline 2014 & $2,73 \times$ \\
\hline 2015 & $2,81 \times$ \\
\hline 2016 & $2,26 \times$ \\
\hline
\end{tabular}

Berdasarkan tabel 5 dapat dilihat bahwa nilai price to book value ratio (PBV) pada PT. Panin Sekuritas Tbk pada tahun 2011 sebesar 1,18 kali, tahun 2012 sebesar 2,40 kali, tahun 2013 naik menjadi 2,80 kali,di tahun 2014 menjadi sebesar 2,73 kali, di tahun 2015 naik menjadi sebesar 2,81 dan ditahun 2016 menurun menjadi sebesar 2,26 kali.

\section{Membandingkan Harga Wajar Saham dengan Harga Pasar Saham}

Tabel 6

Analisis Penilaian Kewajaran Harga Saham Dengan Menggunakan Pendekatan Fundamental Pada PT Panin Sekuritas Tbk Periode 2011-2016

(Dalam Rupiah)

\begin{tabular}{|c|c|c|c|c|}
\hline Saham & Tahun & $\begin{array}{c}\text { Harga } \\
\text { Wajar }\end{array}$ & $\begin{array}{c}\text { Harga } \\
\text { Pasar }\end{array}$ & Hasil \\
\hline \multirow{4}{*}{ PT PaninSekuritas Tbk } & 2011 & 1.193 & 1.290 & Overvalued \\
\cline { 2 - 5 } & 2012 & 3.105 & 3.175 & Overvalued \\
\cline { 2 - 5 } & 2013 & 3.697 & 4.000 & Overvalued \\
\cline { 2 - 5 } & 2014 & 4.679 & 4.975 & Overvalued \\
\cline { 2 - 5 } & 2015 & 4.514 & 4.100 & Undervalued \\
\cline { 2 - 5 } & 2016 & 4.062 & 3.920 & Undervalued \\
\hline
\end{tabular}

Sumber : Data diolah (2017) 
Berdasarkan tabel 6 Hasil dari analisis fundamental saham perusahaan pada PT. Panin Sekuritas,Tbk di tahun 2011 harga wajar sebesar Rp 1.193 dan harga dipasar Rp 1.290 artinya bahwa pada kondisi ini saham perusahaan berada pada kondisi overvalued dimana saham tersebut mahal. Bagi perusahaan ini akan menguntungkan dari penjualan sahamnya, tetapi bagi investor sebaiknya jangan membeli saham tersebut apabila investor tetap ingin membelinya, sebaiknya pikirkan risiko yang akan dihadapi. Seberapa banyak toleransi yang dapat diberikan terhadap premium (selisih antara harga pasar dan harga wajar).

Di tahun 2012 saham perusahaan PT. Panin Sekuritas, Tbk berada pada kondisi overvalued dimana harga wajar sebesar Rp 3.105 dan harga pasar sebesar Rp 3.175 maka perusahaan akan mendapatkan keuntungan atas penjualan sahamnya. Di tahun 2013 dan tahun 2014 saham PT. Panin Sekuritas, Tbk juga berada pada kondisi overvalued dimana pada tahun 2013 harga wajar sebesarRp 3.697 dan harga pasar sebesar $R p$ 4.000 kemudian ditahun 2014 harga wajar sebesar Rp 4.679 dan harga pasar Rp 4.975 pada kondisi ini sebaiknya investor jangan membeli karena mahal tetapi bagi perusahaan ini akan mendapatkan keuntungan dari penjualan sahamnya.

Pada tahun 2015 harga wajar sebesar Rp 4.514 dan harga di pasar sebesar Rp 4.100 artinya pada kondisi ini perusahaan berada pada kondisi undervalued dimana pada kondisi tersebut perusahaan menjual saham yang dimiliki dengan murah karena disebabkan oleh harga wajar yang sama dengan harga pasar. Pada tahun tahun 2016 saham PT. Panin Sekuritas, Tbk juga berada berada pada kondisi undervalued sebaiknya investor membeli saham tersebut karenaharga pasar masih dibawah harga wajaratau murahyaitu harga wajar Rp 4.062 dan harga pasar sebesar Rp 3.920.

Tabel 7

Kriteria kewajaran harga saham dengan pendekatan fundamental

\begin{tabular}{|l|c|c|}
\hline Kriteria & PER & PBV \\
\hline Wajar & $<10$ & $<5$ \\
\hline Tidak Wajar & $>10$ & $>5$ \\
\hline
\end{tabular}

\section{Menilai Kewajaran Harga Saham Menggunakan Rasio Nilai Pasar}

\section{Tabel 8}

Menilai Kewajaran Harga Saham Menggunakan Rasio Nilai Pasar pada PT Panin Sekuritas Tbk Periode 2011-2016

\begin{tabular}{|c|c|c|c|c|c|}
\hline Tahun & Harga Saham & PER & Hasil & PBV & Hasil \\
\hline 2011 & $\operatorname{Rp~} 1.290$ & $3 \times$ & Undervalued & $1,18 \times$ & Undervalued \\
\hline 2012 & $\operatorname{Rp~} 3.175$ & $10 \times$ & Undervalued & $2,40 \times$ & Undervalued \\
\hline 2013 & $\operatorname{Rp~} 4.000$ & $10 \times$ & Undervalued & $2,80 \times$ & Undervalued \\
\hline 2014 & $\operatorname{Rp~} 4.975$ & $14 \times$ & Overvalued & $2,73 \times$ & Undervalued \\
\hline 2015 & $\operatorname{Rp~4.100}$ & $12 \times$ & Overvalued & $2,81 \times$ & Undervalued \\
\hline 2016 & $\operatorname{Rp~} 3.920$ & $40 \times$ & Overvalued & $2,26 \times$ & Undervalued \\
\hline
\end{tabular}

Sumber : Data diolah (2017)

Berdasarkan tabel 8 merupakan hasil penilaian kewajaran harga saham dengan rasio nilai pasar saham perusahaan PT. Panin Sekuritas, Tbk jika dinilai menggunakan pendekatan price earning ratio (PER) pada tahun 2011 sebesar 3 kali, tahun 2012 sebesar 10 kali dan di tahun 2013 sebesar 10 kali yang berada pada kondisi undervalued (murah) atau 
dibawah tingkat kewajaran yaitu sebesar 10 kalimaka layak untuk dibeli, sedangkan pada tahun 2014, tahun 2015 dan tahun 2016 saham PT. Panin Sekuritas, Tbk berada pada kondisi overvalued (mahal) atau berada di atas tingkat kewajaran nilai PER (10 kali) yaitu 14 kali sampai 40 kali. Namun pada kondisi tersebut, saham layak untuk dijual maka perusahaan akan mendapatkan keuntungan dari penjualan sahamnya sehingga pertumbuhan laba juga akan mengalami kenaikan.

Menurut Wira (2011:78) semakin kecil PER suatu saham semakin bagus, namun saham yang memiliki nilai PER tinggi belum tentu termasuk saham yang jelek karena PER tinggi bisa menunjukkan kalau perusahaan itu merupakan perusahaan yang diincar investor.

Sedangkan apabila saham PT Panin Sekuritas Tbk di nilai menggunakan price to book value ratio (PBV) kondisi saham pada tahun 2011 sampai 2016 rata-rata nilai PBV sebesar 1,18 kali sampai 2,81 kali yang artinya berada pada kondisi undervalued (murah) atau dibawah tingkat kewajaran yaitu 4-5 kali nilai bukunya, maka saham tersebut layak untuk dibeli.

\section{G. Kesimpulan dan Saran \\ 1) Kesimpulan}

Berdasarkan perhitungan dan analisis data yang telah dilakukan pada PT. Panin Sekuritas, Tbk dari tahun 2011 sampai tahun 2016, maka dapat diambil kesimpulan yaitu sebagai berikut :

1. Apabila penilaian harga wajar saham menggunakan pendekatan fundamental dengan pendekatan PER atau estimasi PER pada PT. Panin Sekuritas, Tbk pada tahun 2011 sampai tahun 2014 berada pada kondisi overvalued (mahal) karena harga pasar lebih tinggi dari harga wajar, sehingga pada kondisi ini saham layak dijual karena dalam hal ini perusahaan akan mendapatkan keuntungan dari penjualan sahamnya. Kemudian pada tahun 2015 dan tahun 2016 saham PT. Panin Sekuritas Tbk berada pada kondisi undervalued, pada kondisi inilah para investor akan membeli saham tersebut karena harga saham murah.

2. Apabila harga saham dinilai dengan rasio nilai pasar, saham PT. Panin Sekuritas, Tbk jika dinilai menggunakan pendekatan price earning ratio (PER) pada tahun 2011 sampai tahun 2013 berada pada kondisi undervalued(murah) artinya kondisi saham tersebut layak untuk dibeli karena berada dibawah tingkat kewajaran yaitu 10 kali. Sedangkan untuk tahun 2014 sampai tahun 2016 sebaiknya saham tersebut dijual karena berada pada kondisi overvalued (mahal) atau di atas tingkat kewajaran, dengan begitu perusahaan akan mendapatkan keuntungan dari penjualan sahamnya.SedangkanSaham PT. Panin Sekuritas, Tbk apabila dinilai menggunakan price to book value ratio (PBV) saham tersebut berada pada kondisi undervalued atau murah karena dibawah rata-rata harga saham yang diperdagangkan yaitu sebesar 4-5 kali nilai bukunya jadi layak untuk dibeli.

3. Perbedaan dari kedua metode penilaian ini bahwa PER lebih populer dipakai di kalangan analisis saham dan praktisi dan rasio ini merefleksikan penilaian investor atas pertumbuhan 
keuntungan, risiko, dan efisiensi serta kondisi keuangan perusahaan dalam satu paket rasio yang sederhana. Sedangkan PBV lebih sering dipakai untuk membandingkan saham bank dengan nilai bukunya, dengan demikian PBV tidak memuat informasi tentang kemampuan perusahaan untuk menghasilkan laba. Jadi, dari perbedaan tersebut bisa dilihat bahwa PER lebih baik digunakan daripada PBV apabila ingin melihat kemampuan perusahaan dalam menghasilkan laba.

2) Saran

1. Sebaiknya PT. Panin Sekuritas, Tbk dapat mempertahankan atau meningkatkan nilai PER karena PER tinggi bisa menunjukkan bahwa perusahaan tersebut memiliki daya tarik bagi investor, sedangkan meningkatnya nilai PBV karena ada ekspketasi investor yang melihat prospek dan aset yang tidak terlihat dari perusahaan sehingga investor berani menghargai tinggi suatu saham.

2. Hasil dari penelitian ini dapat menjadi rujukan dan bahan pertimbangan investasi bagi investor. Berdasarkan hasil dari penelitian ini, penulis menyarankan kepada para investor hendaknya berinvestasi saham yang masih masuk ke dalam kategori undervalued. Hal ini dikarenakan saham dengan kondisi undervalued memiliki prospek jangka panjang yang cukup baik dan saham dengan kondisi undervalued merupakan saham yang tergolong murah.

3. Untuk peneliti selanjutnya, penulis menyarankan dalam menentukan nilai intrinsik atau harga wajar saham suatu perusahaan dapat dilakukan dengan metode yang berbeda, seperti metode Discounted Dividend Model (DDM), metode Discounted Cash Flow (DCF), Present Value Approach (pendekatan nilai sekarang) atau metode lainnya sehingga hasilnya dapat memberikan informasi tambahan dengan metode yang berbeda. Selain itu, jugadapat menggunakan objek yang lain.

\section{DAFTAR PUSTAKA}

Anoraga, Pandji dan Piji Pakarti. 2006. Pengantar Pasar Modal. Jakarta: Rineka Cipta.

Fahmi, Irham. 2014. Manajemen Keuangan Perusahaan dan Pasar Modal Edisi Pertama.Jakarta:Mitra Wacana Media.

Jogiyanto. 2016. Teori Portofolio dan Analisis Investasi. Yogyakarta: BPFE.

Rusdin. 2007. Pasar Modal. Bandung: Alfabeta.

Sudana, I Made.2011.Manajemen Keuangan Perusahaan Teori \& Praktik. Jakarta: Erlangga.

Sugiyono. 2014. Metode Penelitian Bisnis. Bandung: Alfabeta.

Tandelilin, Eduardus. 2010. Portofolio Dan Investasi (Teori dan Aplikasi) Edisi Pertama. Yogyakarta: PT Kanisius.

Wira, Desmond. 2011. Analisis Fundamental Saham. www.exceedbook.com. 